\title{
CRISPR-Cas9 Gene Editing for Fruit and Vegetable Crops: Strategies and Prospects
}

\author{
Lili Wan ${ }^{1}{ }^{1}$, Zhuanrong Wang ${ }^{1}$, Mi Tang ${ }^{1, *}$, Dengfeng Hong ${ }^{2}$, Yuhong Sun ${ }^{1}$, Jian Ren ${ }^{1}$, Na Zhang ${ }^{1}$ \\ and Hongxia Zeng ${ }^{1}$ \\ 1 Institute of Crop, Wuhan Academy of Agricultural Sciences, Wuhan 430065, China; \\ wanlili13226@163.com (L.W.); zhuanrongwang@163.com (Z.W.); sunyh68@163.com (Y.S.); \\ 18571636516@163.com (J.R.); zhangna@wuhanagri.com (N.Z.); 18971053198@163.com (H.Z.) \\ 2 National Key Laboratory of Crop Genetic Improvement, Huazhong Agricultural University, \\ Wuhan 430070, China; dfhong@mail.hzau.edu.cn \\ * Correspondence: xtgyjs@wuhanagri.com; Tel.: +86-027-62302993
}

check for updates

Citation: Wan, L.; Wang, Z.; Tang, M.; Hong, D.; Sun, Y.; Ren, J.; Zhang, N.; Zeng, H. CRISPR-Cas9 Gene Editing for Fruit and Vegetable Crops: Strategies and Prospects. Horticulturae 2021, 7, 193. https:// doi.org/10.3390/horticulturae7070193

Academic Editor: Yuyang Zhang

Received: 1 June 2021

Accepted: 10 July 2021

Published: 14 July 2021

Publisher's Note: MDPI stays neutral with regard to jurisdictional claims in published maps and institutional affiliations.

Copyright: (c) 2021 by the authors. Licensee MDPI, Basel, Switzerland. This article is an open access article distributed under the terms and conditions of the Creative Commons Attribution (CC BY) license (https:// creativecommons.org/licenses/by/ $4.0 /)$.

\begin{abstract}
Fruit and vegetable crops are rich in dietary fibre, vitamins and minerals, which are vital to human health. However, many biotic stressors (such as pests and diseases) and abiotic stressors threaten crop growth, quality, and yield. Traditional breeding strategies for improving crop traits include a series of backcrosses and selection to introduce beneficial traits into fine germplasm, this process is slow and resource-intensive. The new breeding technique known as clustered regularly interspaced short palindromic repeats (CRISPR)-CRISPR-associated protein-9 (Cas9) has the potential to improve many traits rapidly and accurately, such as yield, quality, disease resistance, abiotic stress tolerance, and nutritional aspects in crops. Because of its simple operation and high mutation efficiency, this system has been applied to obtain new germplasm resources via gene-directed mutation. With the availability of whole-genome sequencing data, and information about gene function for important traits, CRISPR-Cas9 editing to precisely mutate key genes can rapidly generate new germplasm resources for the improvement of important agronomic traits. In this review, we explore this technology and its application in fruit and vegetable crops. We address the challenges, existing variants and the associated regulatory framework, and consider future applications.
\end{abstract}

Keywords: CRISPR/Cas; gene knockout; genome editing; germplasm resource; precision editing; regulatory framework; trait improvement

\section{Introduction}

Fruit and vegetable crops are rich in cellulose, vitamins, trace elements, minerals, and other important nutrients, which are essential in the human diet [1]. However, climate and environmental changes potentially threaten the production and supply of fruits and vegetables [2]. Humans have long domesticated and cultivated wild species. Crossbreeding technology enables breeders to improve varieties by crossing selected dominant varieties [3]. However, with long-term artificial selection, the shortcomings of conventional breeding become increasingly prominent, mainly in the excessive dependence on naturally occurring allelic variation. There are limited genetic germplasm resources for improving target traits, and conventional breeding can expose many adverse traits, thereby reducing breeding efficiency [4]. Although traditional breeding can produce new vegetable cultivars with high yield, good quality and disease resistance, with the increasing global population and continuous food-supply demands, it is important to rapidly select new varieties to meet market demands [5]. The development and application of emerging methods in crop biotechnology can promote high-efficiency and precise varietal breeding [6].

Genetic engineering has been used to improve the responses to biotic and abiotic stress, and to improve the quality of fruits and vegetables. In 1994, a storage resistant transgenic tomato was approved by the Food and Drug Administration (FDA) [7]. For papaya, 80\% 
of the market was supplied with high-yield transgenic papaya with high resistance to the cyclic spot virus [8]. However, in order to ensure safety in planting processes and product consumption, genetically modified (GM) plant development and application are strictly legislated and regulated, greatly delaying the development to market of transgenic cultivars [9]. In 2013, CRISPR-Cas-mediated gene editing was developed as a tool to study plant gene function. Over the next two years, many new gene-edited crop germplasm resources emerged. In 2016, the US FDA approved the CRISPR gene editing of a waxy corn null segregant line and an anti-browning mushroom (Agaricus bisporus) for the market, without applying the strict regulatory process required for GM crops $[10,11]$. This indicates that CRISPR gene editing has already succeeded in promoting the development of crop cultivars.

In this review, we summarise the mechanisms underlying CRISPR technology, recent applications in fruit and vegetable crops, and improvements in CRISPR-Cas systems. We further outline CRISPR-associated regulatory frameworks that enable commercialisation of gene edited crops in different countries. Finally, we discuss the future challenges and opportunities for introducing desirable alleles and improving many traits.

\subsection{The Discovery and Development of CRISPR Technology}

CRISPR-associated (Cas) genes were first discovered in the Escherichia coli genome in 1987 and were officially named by the Dutch scientist who identified them [12]. In 2005, it was discovered that many CRISPR spacers consist of short sequences that are highly homologous with sequences originating from extrachromosomal DNA. The Cas-encoded protein can combine with the CRISPR transcription products and with the homologous foreign DNA sequences to form a protein-RNA complex, which can cut the foreign DNA fragments. The primary function of the CRISPR complex in bacteria and archaea is to integrate specific fragments of exogenous DNA (from invading phages or other sources) into their own genomes to become interval sequences. During subsequent invasion by foreign DNA, the specific recognition system is then activated, providing an acquired immune defence function [13-15].

CRISPR-Cas technology has been successfully applied to the editing of human, animal, and plant genomes, and has been developed for use in drug screening, animal domestication, and food science research [16-18]. There are three main types of CRISPR-Cas systems. Types I and III use a large multi-Cas protein complex for interference [19]. Type II requires only a simple effector-module architecture to accomplish interference via its two signature nuclease domains, RuvC and HNH [20]. Among various CRISPR nucleases, type II Cas9 from Streptococcus pyogenes (SpCas9) is the most widely used in CRISPR-Cas technology [21]. The sgRNA-Cas complex recognises the protospacer adjacent motif (PAM) and Cas9 cleaves the target DNA to generate a double-strand break (DSB), triggering cellular DNA repair mechanisms (Figure 1). In eukaryotes, DSBs have two main repair mechanisms. The first is nonhomologous end joining (NHEJ). In the absence of a homologous repair template, the NHEJ repair pathway is activated at the DSB site, thus disrupting gene function. The second is homology directed repair (HDR). If a donor DNA template homologous to the sequence surrounding the DSB site is available, the HDR pathway is initiated, precisely introducing specific mutations such as insertion or replacement of desired sequences into the break sites [22]. Using a donor DNA as a template, gene targeting (GT) can precisely modify a target locus to repair DNA DSBs.

Several strategies are used to improve the homologous recombination frequency between a genomic target and an exogenous homologous template donor. Most of the strategies focus on enhancing the number of donor repair templates using virus replicons [23], suppressing the NHEJ pathway [24], and timing DSB induction at target sites to coincide with donor repair template delivery in plant cells [25]. Finally, the recombination frequency can be enhanced by treatment with Rad51-stimulatory compound1 (RS-1) [26]. 


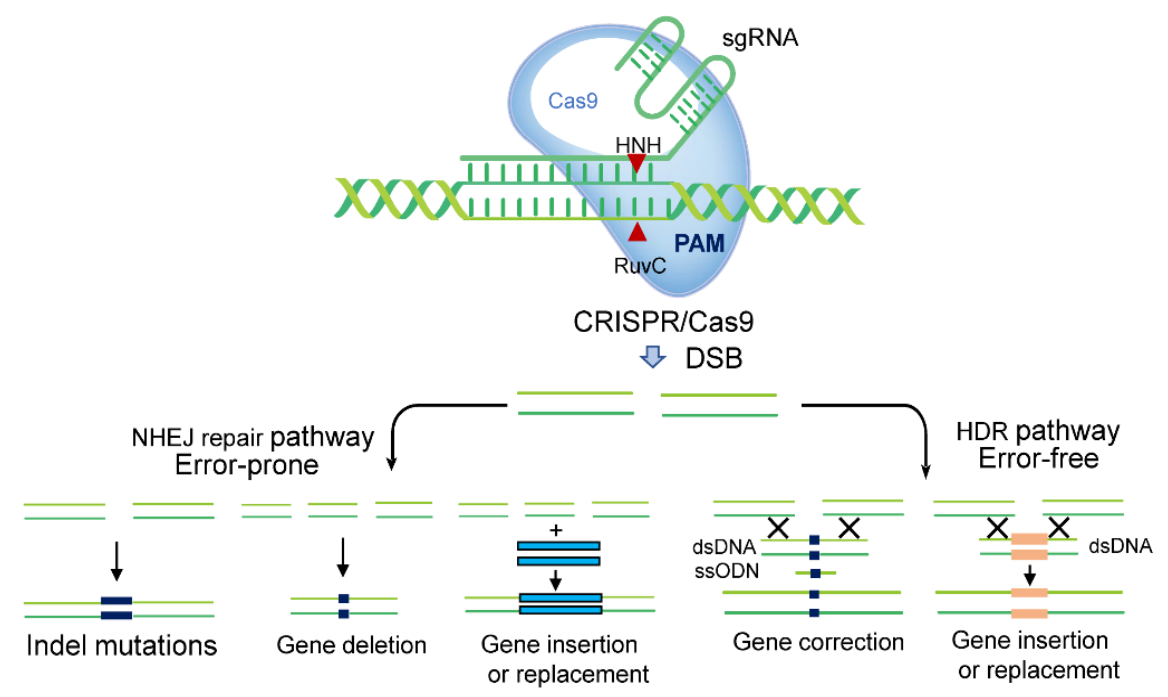

Figure 1. The potential applications of CRISPR-Cas systems in genome editing. CRISPR-Cas systems mediated genome modification depending on the two main double-strand break (DSB) repair pathways. Indel mutation and gene deletion are outcomes of the dominant nonhomologous end joining (NHEJ) repair pathway. Gene insertion, correction, and replacement, using a DNA donor template, are outcomes of the homology directed repair (HDR) pathway.

\subsection{Development of the CRISPR-Cas System in Plant Studies}

Since the CRISPR-Cas system was first adopted for plant genetic engineering in 2013, numerous efforts have been made to develop it into a more powerful tool, for instance, to enable precisely targeted DNA mutations or genetic modifications [27]. CRISPR-Cas can now target the open reading frame, untranslated region, and promoter region of a target coding gene, as well as noncoding RNAs [28-30]. Single-base mutations at genomic targets have also been achieved by nickase Cas9 (nCas9) or catalytically inactive Cas9 (dead Cas9; dCas9) variants fused with cytosine or adenine deaminases, without inducing DSBs [31]. Cas9 proteins have been developed extensively to broaden PAM preferences. Cas9 orthologs which possess not only the canonical NGG PAM, but also NG and other PAMs, will expand the repertoire of CRISPR-Cas9 genome editing in plants [32].

\subsection{CRISPR-Cas9 in Fruit and Vegetable Crop Improvement}

In 2014, CRSPR-Cas9 was used to create the first needle-leaf mutant in tomato, by knocking out Argonaute 7 [33]. Many studies have since been published on its possible applications in protecting plants against biotic and abiotic stresses, and improving fruit quality, plant architecture, and shelf life [34]. Currently, the system is in the research stage for many fruits and vegetables crops, such as cabbage, mustard, tomato, and watermelon.

Most gene-editing studies have evaluated mutation efficiency in terms of the number of albino plants obtained after mutation of the endogenous phytoene desaturase (PDS) gene. The disruption of PDS impairs the production of chlorophyll and carotenoid, generating an easily identifiable albinism phenotype in plants. However, the products of gene editing obtained in this way have no economic value [35-37]. Because of its high economic value and the availability of Agrobacterium-mediated transformation, tomato has become a model crop for testing CRISPR-Cas9 applications (Figure 2). 


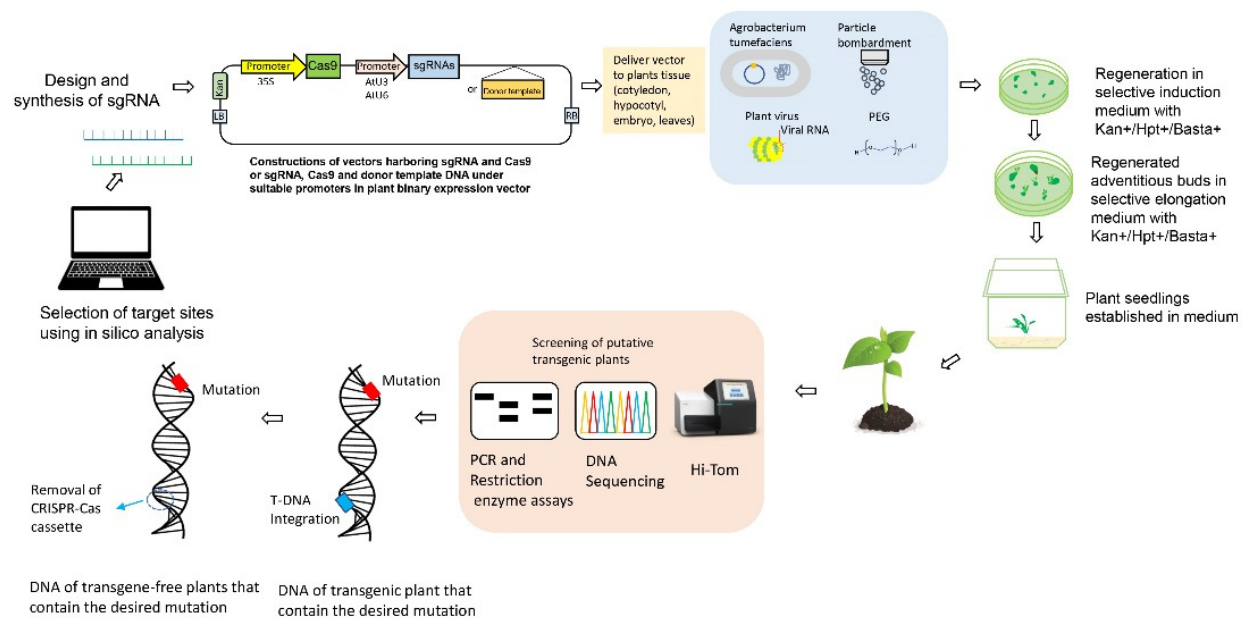

Figure 2. CRISPR-Cas9 mediated genome editing. (I) Selection of the desired genomic DNA target, and recognition of protospacer adjacent motif (PAM) sequences before $20 \mathrm{bp}$ sequences. Design of the sgRNA using online bioinformatics tools. (II) Cloning of designed sgRNAs, and binary vector construction using promoters. (III) The delivery of CRISPR-Cas editing reagents into plant cells. The vector can be transferred into the plant via Agrobacterium tumefaciens, nanoparticles, biolistic bombardment, or polyethylene glycol (PEG). Alternatively, plant RNA viruses have been used to induce heritable genome editing. When the cassette harbouring the sgRNA, RNA mobile element, and tobacco rattle virus (TRV) is transformed into the Cas9 expressing plants, the systemic spread of sgRNA will introduce heritable genome editing. (IV) Plant transformation and development of transgenic plants. (V) Genotyping of transgenic plants. (VI) Transgene-free plants with the desired mutation are obtained.

\subsubsection{Improvement of Biotic Stress Resistance}

Two strategies have been used to improve plant resistance to viruses: (1) designing sgRNAs and targeting the virus genome; or (2), modifying the fruit crop genes in the antiviral pathway. The binding of virus genome linked protein $(\mathrm{VPg})$ to the plant protein 'eukaryotic translation initiation factor $4 \mathrm{E}^{\prime}$ ( $\mathrm{eIF} 4 \mathrm{E}$ ) is key in $\mathrm{Y}$ virus infection of plants. Mutation of a key site of eIF4E can affect the virus-plant interaction, and mediate plant resistance to this virus [38]. In cucumbers, using CRISPR-Cas to target the $\mathrm{N}^{\prime}$ and $\mathrm{C}^{\prime}$ ends of eIF4E-produced nontransgenic homozygous plants in the T3 generation; these showed immunity to cucumber vein yellow virus and pumpkin mosaic virus, and resistance to papaya ring spot mosaic virus (PRSV-W) [39].

CRISPR-Cas9 can generate mutations in the coding and noncoding regions of geminivirus, effectively reducing its pathogenicity. In Nicotiana benthamiana, sgRNA-Cas9 constructs target beet severe curly top virus (a geminivirus), inhibiting its accumulation in leaves [40]. Geminivirus noncoding-region mutations are believed to reduce or even inhibit its replication ability. Compared with coding-region mutations, noncoding-region mutations generate fewer viral variants [41].

Fungi cause many diseases, potentially causing severe losses in crop yield and quality. For instance, downy and powdery mildews cause serious economic losses in tomato [42]. Arabidopsis thaliana DMR6 (down mildew resistant) is a member of the 2-oxoglutarate oxygenase $\mathrm{Fe}(\mathrm{II})$-dependent superfamily and is involved in salicylic acid homeostasis. Overexpression of DMR6 in plants can reduce susceptibility to downy mildew [43]. The DMR6 mutation obtained using CRISPR-Cas9 to knock out the homologous genes in tomato showed resistance to Pseudomonas syringae, Phytophthora and Xanthomonas spp. [44]. Mlo1 (Mildew resistant locus 1) encodes a membrane-associated protein and is a powdery mildew disease-sensitivity gene. In tomato, Mlo1 mutants obtained via gene editing exhibited resistance to the powdery mildew Oidium neolycopersici. Further, a mutant free of mlo1 T-DNA was obtained by selfing T0 generation plants [45]. 
The fungal pathogen Fusarium oxysporum can cause Fusarium wilt disease in fruit and vegetable crops [46]. In tomatoes, Solyc08g075770-knockout via CRISPR-Cas9 resulted in sensitivity to Fusarium wilt disease [47]. In watermelons, the knockout of Clpsk1, encoding the Phytosulfokine (PSK) precursor, confers enhanced resistance to Fusarium oxysporum f.sp.niveum (FON) [48]. Botrytis cinerea, an airborne plant pathogen that infects fruit and vegetable crops, causes great economic losses. Its initial symptoms are not obvious, and the lack of effective pesticides makes its prevention and control difficult. Pathogens can be effectively controlled in crops by the use of genetic resources that convey heritable resistance. In tomatoes, mutations in MAPK3 (mitogen-activated protein kinase 3) produced using CRISPR-Cas9 induce resistance to Botrytis cinerea [49].

The bacterial pathogen Pseudomonas syringae causes leaf spot diseases in crops, severely impacting the yield and sensory qualities of fruits and vegetables. In Arabidopsis thaliana, CRISPR-Cas9 was used to mutate the C-terminal jasmonate domain (JAZ2 $\triangle$ jas) of JAZ2 (jasmonate ZIM domain protein 2), causing expression of JAZ2 repressors; these repressors confer resistance to Pseudomonas syringae [50].

\subsubsection{Abiotic Stress Resistance Improvement}

With climate change, crop production is exposed to increased potential risks of abiotic stress. Although traditional breeding can to some extent ensure stable crop production, the application of new technologies to rapidly obtain new crop germplasm resources capable of responding to abiotic stress is essential for accelerating the cultivation of new varieties [51]. The emergence of CRISPR-Cas9 gene editing has shortened the time required to create new varieties. Brassinazole-resistant 1 gene (BZR1) participates in various brassinosteroid (BR) mediated development processes. The CRISPR mediated mutation in BZR1 impaired the induction of RESPIRATORY BURST OXIDASE HOMOLOG1(RBOH1) and the production of $\mathrm{H}_{2} \mathrm{O}_{2}$. Exogenous $\mathrm{H}_{2} \mathrm{O}_{2}$ recovered the heat tolerance in tomato bzr1 mutant [52]. Further, new cold- and drought-tolerant germplasms can be created using gene-editing, for instance, of CBF1 (C-repeat binding factor 1), which regulates cold tolerance in plants, and MAPK3, which participates in the drought stress response to protect plant cell membranes from peroxidative damage in tomatoes [53,54].

\subsubsection{Herbicide Resistance Improvement}

Weeds are an important cause of stress that affect vegetable yield and quality, and selective herbicides are often used to control weed growth during cultivation. To obtain herbicide-resistant fruits and vegetables for field production, CRISPR-Cas9 gene editing was used for site-directed mutagenesis of the herbicide target gene acetolactate synthase (ALS) in watermelon, yielding a herbicide-resistant watermelon germplasm [55]. Cytidine base editing $(\mathrm{CBE})$ was used for cytidine editing of key ALS sites in tomato and potato, resulting in amino acid mutations. Up to $71 \%$ of edited tomato plants exhibited resistance to the pesticide chlorsulfuron, and of the edited tomato and potato plants, $12 \%$ and $10 \%$, respectively, were free of GM components [56]. Phelipanche aegyptiaca, an obligate weedy plant parasite, requires the host roots to release the plant hormone strigolactone (SL) to promote seed germination; CRISPR-Cas9 was used to mutate carotenoid dioxygenase 8 (CCD8), a key enzyme in the carotenoid synthesis pathway that produces SLs in tomato, and More Axillary Growth1 (MAX1), which is involved in the synthesis of SLs, thereby significantly reducing SL content, and creating $P$. aegyptiaca-resistant tomato plants $[57,58]$.

\subsubsection{Fruit and Vegetable Quality Improvement}

The primary goal in fruit and vegetable breeding is to improve quality and prolong shelf life after harvest. Quality refers to both external and internal factors. External quality refers to fruit size, colour, and texture, which can be discerned by the naked eye. Internal quality must be measured using equipment, and includes the levels of nutrients such as sugars, vitamins, and bioactive compounds including lycopene, anthocyanins, and malate. For example, in tomato, the ovary locule number, which determines $50 \%$ of the genetic 
variation in fruit size, is determined by multiple QTLs [59]. Researchers at Cold Spring Harbor Laboratory designed eight sgRNAs and used CRISPR-Cas9 to edit the promoter region of the tomato CLAVATA-WUSCHEL (CLV-WUS) stem cell gene CLV3 to obtain fruits that are larger and more numerous than wild-type fruits [60]; editing of fruit-size determining QTLs, such as the QTLs for locule number (lc) and fasciated number (fas), generated germplasm resources with an increased number of locules [61].

Fruit and vegetable colour and texture are important traits for consumers. For example, European and American consumers prefer red tomatoes, whereas Asian consumers prefer pink tomatoes [62,63]. CRISPR-Cas was used to modify phytoene synthase 1 (PSY1), MYB transcription factor 12 (MYB12), and anthocyanin 2 (ANT2) to obtain yellow, pink, and purple tomatoes, respectively [64-66]. The carotenoid isomerase gene of Chinese kale (BoaCRTISO) is responsible for catalysis, then conversion of lycopene precursors to lycopene. When BoaCRTISO was targeted and edited, the colour of mutants changed from green to yellow [67]. The primary goal of improving the intrinsic quality of fruits and vegetables is to improve their nutrient and bioactive compound content. Carbohydrates and vitamins are essential nutrients. Many genes are involved in the synthesis and metabolism of sucrose and carotenoids. One of the carotenoids, provitamin A, can be absorbed by the human body and converted into vitamin A. For example, CRISPR-Cas was used to knock out MPK20 (mitogen-activated protein kinase 20), blocking the transcription and protein products of multiple genes in the sucrose metabolism pathway [68]. Biofortification, the biotechnological improvement of the absorption, transport, and metabolism of minerals by plants, increases the levels of micronutrients that are beneficial to human health; long-term consumption of these micronutrients can effectively prevent cardiovascular disease and cancer [69].

Anthocyanins [70], malate [71], $\gamma$-aminobutyric acid (GABA) [72], and lycopene [73] are bioactive compounds. Adjusting key metabolic-pathway-related genes via CRISPRCas9 can enrich these nutrients in fruits. For example, in tomatoes, butylamine content was increased 19-fold through editing multiple genes in the GABA synthesis pathway, and malate content was improved by regulating aluminium-activated malate transporter (ALMT9) [72].

CRISPR-Cas9 can also be used to reduce the content of substances in vegetables that are not conducive to human health, by targeting mutations that inactivate genes in biosynthetic pathways. In potato tubers, for example, excessive content of steroidal glycoalkaloids (SGAs), such as $\alpha$-solanine and $\alpha$-chaconine, affects their taste and makes them less safe for human consumption, hence low content is an indicator of high quality. CRISPR-Cas9 was used to delete St16DOX (steroid 16 $\alpha$-hydroxylase) in the potato SGA biosynthetic pathway, resulting in SGA-free potato lines [74].

Prolonged shelf-life is an important breeding goal in fruit and vegetable production. CRISPR was used to knock out ripening inhibitor (RIN) or DNA demethylase (DNA demethylase 2, DML2) to slow fruit ripening, thereby prolonging their shelf life. However, regulating these two genes in fruit alters peel colour and reduces flavour and nutritional value, severely reducing the fruit's palatability and sensory qualities $[75,76]$. In tomatoes, inhibiting the expression of the pectate lyase $(P L)$ and alcobaca $(A L C)$ genes effectively extended shelf life, without affecting the sensory qualities or nutritional value $[77,78]$.

\subsubsection{Application of CRISPR-Cas9 to Crop Domestication}

The domestication of wild species into commercial cultivated species requires changes in numerous crop traits, including seed setting, size, consistency of maturation, flowering, photoperiod sensitivity, and the nutritional value of the fruit [79]. Plant domestication mostly affects the genes controlling plant morphology, plant growth habit, floral induction, fruit size and number, dispersal, and architecture, as well as the nutritional composition. To achieve the ideotype, alleles controlling favourable nutritional attributes and stress resilience from wild relatives are introduced into cultivated species via traditional domestication technology, but this process is very time-consuming in bringing about changes 
to many loci. With its ability to precisely manipulate the genome, CRISPR-Cas9 can substantially accelerate de novo domestication.

The tomato is a model crop for artificial domestication using CRISPR-Cas9. In tomato plants, the joint is a weak region of the stem which allows the fruit to drop from the plant, making the fruit prone to fall after ripening, thus improving seed dispersal. Many years of artificial domestication based on harvesting habits has generated cultivars with jointless fruit stems, in which the fruit do not fall after maturation [79,80]. Roldan et al. [81] used CRISPR-Cas to mutate MBP21 (MADS-box protein 21), obtaining a new jointless germplasm resource.

Parthenocarpy (fertilisation-independent seedless fruit development) is an important agronomic fruit and vegetable trait and can help ensure stable yield in fluctuating environments. It satisfies consumer preferences for seedless over seeded fruits and provides savings in energy consumption when separating the seeds for industrial production. In tomatoes, SIAGL6 (SlAGAMOUS-like 6) is essential for parthenocarpy during high temperature stress. SIAGL6-mutant plants grow normally and have the same fruit weight and morphology as wild-type plants. Therefore, this gene is an important resource for creating new parthenocarpic germplasms. Homozygous or biallelic mutant plants obtained by modifying SIAGL6 produced parthenocarpic fruits and fruits with a maximum of 10 seeds, respectively [82]. CRISPR-Cas has also been used to knock out SIARF7 (auxin response factor 7) and SIIAA9 (indole-3-acetic acid inducible 9) to obtain seedless tomatoes. Seedless tomatoes are obtained from the $\mathrm{T} 0$ generation of the biallelic and homozygous SIIAA9-mutant Micro-Tom cultivar and the commercial Ailsa Craig cultivar [83,84].

Plant yield depends primarily on the number of flowers, which in turn is determined by inflorescence structure. BOP (blade-on-petiole) is homologous to genes associated with leaf complexity and silique dehiscence in tomato and Arabidopsis. Knocking out BOP via CRISPR-Cas9 altered inflorescence morphology. CRISPR-Bop1/2/3 triple mutants flower faster and have simpler inflorescence structure than wild-type plants [85]. The site-directed editing of six key genes that determine yield in wild tomatoes (Solanum pimpinellifolium) has resulted in morphological changes in aspects such as size, fruit number, and nutritional composition [86]. In domesticated wild tomatoes, genes associated with morphology, number of flowers, fruit yield, and vitamin C synthesis have been improved by editing their coding sequences, cis-regulatory sequences, and upstream open reading frames [81]. APETALA2a (AP2a), NON-RIPENING (NOR), and FRUITFULL (FUL1/TDR4 and FUL2/MBP7) have been modified to accelerate tomato maturation, producing plants that mature earlier in natural environments [87].

Crop sensitivity to photoperiod restricts their planting areas and regulating the photoperiod-associated genes can accelerate domestication. The disruption of self-pruning 5G (SP5G) generated a rapid surge in flowering that leads to an early fruit harvest [88].

Dwarf-crop breeding is an important direction in domestication research, as dwarf plants are resistant to lodging under high wind conditions. Compared with normal plants, it is more convenient to pick fruits from dwarfed plants [89]. Dwarf plants transport nutrients more readily over the shorter distances from the roots to the leaves [89]. The application of CRISPR-Cas9 technology in the genomes of several commercially important fruit and vegetables has been achieved as outlined in Table 1. 
Table 1. List of target genes and traits modified via CRISPR-Cas9 technology in fruit and vegetable crops.

\begin{tabular}{|c|c|c|c|c|c|}
\hline Crop Species & Target & Mutation & Transformation Method & Trait Modification & References \\
\hline Tomato & SlAGO7 & Loss of function & Agrobacterium-mediated transformation & Wiry phenotype & [33] \\
\hline Cabbage & BoPDS & Loss of function & Agrobacterium-mediated hypocotyl transformation & Albino phenotype & [35] \\
\hline Chinese kale & BaPDS1BaPDS2 & Loss of function & Agrobacterium-mediated cotyledon transformation & Albino phenotype & {$[37]$} \\
\hline Cucumber & elF4E & Loss of function & Agrobacterium-mediated cotyledon transformation & $\begin{array}{l}\text { Resistance against cucumber vein } \\
\text { yellowing virus, zucchini yellow } \\
\text { mosaic virus, and papaya ring spot } \\
\text { mosaic virus }\end{array}$ & {$[38]$} \\
\hline Tomato & ClDMR6 & Loss of function & Agrobacterium-mediated cotyledon transformation & Resistance against downy mildew & {$[44]$} \\
\hline Tomato & ClMlo1 & Loss of function & Agrobacterium-mediated cotyledon transformation & Resistance against downy mildew & {$[45]$} \\
\hline Tomato & Solyc08g075770 & Loss of function & Agrobacterium-mediated cotyledon transformation & Fusarium wilt susceptibility & [47] \\
\hline Watermelon & ClPSK1 & Loss of function & $\begin{array}{l}\text { Agrobacterium-mediated cotyledon } \\
\text { transformation }\end{array}$ & $\begin{array}{l}\text { Resistance to Fusarium oxysporum } \\
\text { f.sp. niveum }\end{array}$ & {$[48]$} \\
\hline Tomato & MAPK3 & Loss of function & Agrobacterium-mediated cotyledon transformation & Resistance to Botrytis cinerea & [49] \\
\hline Tomato & CBF1 & Loss of function & Agrobacterium-mediated cotyledon transformation & Decrease in chilling stress tolerance & {$[53]$} \\
\hline Tomato & SIMAPK3 & Loss of function & Agrobacterium-mediated cotyledon transformation & $\begin{array}{l}\text { Decrease in drought stress } \\
\text { tolerance }\end{array}$ & {$[54]$} \\
\hline Watermelon & ClALS & Site-directed mutagenesis & Agrobacterium-mediated cotyledon transformation & Herbicide resistance & [55] \\
\hline Tomato and Potato & StALS2 & Site-directed mutagenesis & Agrobacterium-mediated transformation & Herbicide resistance & [56] \\
\hline Tomato & $\begin{array}{l}\text { Carotenoid cleavage } \\
\text { dioxygenase } 8 \text { (CCD8) }\end{array}$ & Loss of function & Agrobacterium-mediated transformation & $\begin{array}{l}\text { Resistance against } \\
\text { Phelipanche aegytiaca }\end{array}$ & {$[57]$} \\
\hline Tomato & More Axillary Growth1 (MAX1) & Loss of function & Agrobacterium-mediated transformation & $\begin{array}{l}\text { Resistance against } \\
\text { Phelipanche aegytiaca }\end{array}$ & {$[58]$} \\
\hline Tomato & SP,SP5G,CLV3, WUS, GGP1 & $\begin{array}{l}\text { Cis-regulatory variation } \\
\text { and loss of function }\end{array}$ & Agrobacterium-mediated transformation & $\begin{array}{l}\text { Introduction of desirable traits } \\
\text { with morphology, flower number, } \\
\text { fruit size and number, and ascorbic } \\
\text { acid synthesis }\end{array}$ & {$[60]$} \\
\hline
\end{tabular}


Table 1. Cont.

\begin{tabular}{|c|c|c|c|c|c|}
\hline Crop Species & Target & Mutation & Transformation Method & Trait Modification & References \\
\hline Tomato & $\begin{array}{l}\text { SlWUS CarG element, } \\
\text { SlCLV3 promoter }\end{array}$ & Cis-regulatory variation & Agrobacterium-mediated transformation & $\begin{array}{l}\text { Fruit size, inflorescence branching, } \\
\text { and plant architecture }\end{array}$ & {$[61]$} \\
\hline Tomato & PSY1 & $\begin{array}{l}\text { Different mutations in } \\
\text { alleles }\end{array}$ & Agrobacterium-mediated cotyledon transformation & Yellow-coloured tomato & {$[64]$} \\
\hline Tomato & MYB12 & $\begin{array}{l}\text { Different mutations in } \\
\text { alleles }\end{array}$ & Agrobacterium-mediated cotyledon transformation & Pink-coloured tomato & {$[65]$} \\
\hline Tomato & ANT2 & Gene insertion & Agrobacterium-mediated cotyledon transformation & Purple-coloured tomato & [66] \\
\hline Chinese kale & BoaCRTISO & $\begin{array}{l}\text { Gene insertion and } \\
\text { replacement }\end{array}$ & Agrobacterium-mediated transformation & $\begin{array}{l}\text { Colour of mutants changed from } \\
\text { green to yellow }\end{array}$ & {$[67]$} \\
\hline Tomato & MPK20 & Loss of function & Agrobacterium-mediated transformation & $\begin{array}{l}\text { Repression of genes controlling } \\
\text { sugar and auxin metabolism }\end{array}$ & {$[68]$} \\
\hline Tomato & $\begin{array}{l}\text { GAD2,GAD3,SlyGABA- } \\
\text { TP1,SlyGABA-TP2,SlyGABA- } \\
\text { TP3,SlyCAT9,SlySSADH }\end{array}$ & $\begin{array}{l}\text { Autoinhibitory } \\
\text { domain deletion }\end{array}$ & Agrobacterium-mediated transformation & $\begin{array}{l}\text { Increase in } \gamma \text {-aminobutyric acid } \\
\text { (GABA) content }\end{array}$ & {$[72]$} \\
\hline Tomato & $\begin{array}{l}\text { SGR1,lycopene e-cyclase (LCY-E), } \\
\text { beta-lycopene cyclase (Blc), lycopene } \\
\beta \text {-cyclase1(LCY-B1) and LCY-B2 }\end{array}$ & Loss of function & $\begin{array}{l}\text { Agrobacterium-mediated apical segments of } \\
\text { hypocotyls transformation }\end{array}$ & Lycopene content & {$[73]$} \\
\hline Potato & 16 $\alpha$-hydroxylation (St16DOX) & Loss of function & Agrobacterium-mediated shoot transformation & $\begin{array}{l}\text { Steroidal glycoalkaloid } \\
\text { (SGA) biosynthesis }\end{array}$ & {$[74]$} \\
\hline Tomato & Ripening inhibitor (RIN) & $\begin{array}{l}\text { Single base insertion or } \\
\text { deletion of more than } \\
\text { three bases }\end{array}$ & Agrobacterium-mediated transformation & $\begin{array}{l}\text { MADS-box transcription factor } \\
\text { regulating fruit ripening }\end{array}$ & [75] \\
\hline Tomato & DNA demethylases (SIDML2) & Loss of function & Agrobacterium-mediated cotyledon transformation & $\begin{array}{l}\text { Activation and inhibition of } \\
\text { fruit ripening }\end{array}$ & [76] \\
\hline Tomato & $\begin{array}{l}\text { Enzymes pectate lyase }(P L), \\
\text { Polygalacturonase } 2 \mathrm{a}(P G 2 a), \\
\text { and } \beta \text {-galactanase }(T B G 4)\end{array}$ & $\begin{array}{l}\text { Generation of a range of } \\
\text { CRISPR alleles }\end{array}$ & Agrobacterium-mediated transformation & Pectin degradation control & [77] \\
\hline Tomato & Alcobaca $(S L A L C)$ & Loss of function & $\begin{array}{l}\text { Agrobacterium-mediated } \\
\text { hypocotyls transformation }\end{array}$ & Long shelf-life & {$[78]$} \\
\hline
\end{tabular}


Table 1. Cont.

\begin{tabular}{|c|c|c|c|c|c|}
\hline Crop Species & Target & Mutation & Transformation Method & Trait Modification & References \\
\hline Tomato & SlMBP21 & Loss of function & $\begin{array}{l}\text { Agrobacterium-mediated } \\
\text { transformation }\end{array}$ & Jointless fruit stem & [81] \\
\hline Tomato & SIAGAMOUS-LIKE 6 (Sl AGL6) & Loss of function & $\begin{array}{l}\text { Agrobacterium-mediated } \\
\text { transformation }\end{array}$ & Parthenocarpic & [82] \\
\hline Tomato & ARF7 & Loss of function & $\begin{array}{l}\text { Agrobacterium-mediated } \\
\text { transformation }\end{array}$ & Parthenocarpic & [83] \\
\hline Tomato & SIIAA9 & Loss of function & $\begin{array}{l}\text { Agrobacterium-mediated leaf disk } \\
\text { transformation }\end{array}$ & Parthenocarpic & [84] \\
\hline Tomato & Blade-on-petiole (SlBOP) & Loss of function & $\begin{array}{l}\text { Agrobacterium-mediated cotyledon segments } \\
\text { transformation }\end{array}$ & $\begin{array}{l}\text { Early flowering with simplified } \\
\text { inflorescence architecture }\end{array}$ & [85] \\
\hline Tomato & Self-pruning 5G(SlSP5G) & cis-regulatory variation & $\begin{array}{l}\text { Agrobacterium-mediated } \\
\text { transformation }\end{array}$ & Day-length-sensitive flowering & [88] \\
\hline
\end{tabular}




\subsection{Improvements to CRISPR-Cas9 Gene-Editing Systems}

\subsubsection{Production of Non-GM Plants Using CRISPR-Cas9 Gene Editing}

Most fruit crops have heterozygous genotypes, hybrid incompatibility, and long growth periods. Some have complex triploid or polyploid genomes [90]. During the last 20 years, innovative breeding technology employing genetic engineering has provided a favourable way to accelerate crop improvement for such species [91]. For example, the introduction of foreign DNA fragments when creating transgenic lines may block the function of endogenous genes and affect the expression of adjacent genes. In contrast to transgenic approaches, CRISPR/Cas9 technology is able to generate nontransgenic plants. Because CRISPR/Cas9 expression cassettes and their target sites are located at different positions of the genome, segregation and removal of the CRISPR/Cas9 cassettes is possible via subsequent selfing or crossing; however, this is not feasible in most fruit crops, because of their complex, highly heterozygous, and polyploid genomes, and because they are usually vegetatively propagated.

Fruit trees have a long juvenile stage and take several years to reach the reproductive stage. In such cases, the CRISPR/Cas9 components can be transiently expressed in the nucleus and function for a short time to induce precise mutations. This means that transgene-free edited plants can be generated, since the CRISPR/Cas9 expression cassette is not integrated into the genome. Currently, the overall efficiency of the transient system for the production of T-DNA-free edited apple lines is very low (0.4\%) [92]; thus, the next step is to improve editing efficiency and to make this system suitable for other crops.

Preassembled CRISPR-Cas-sgRNA ribonucleoproteins (RNPs) can be delivered into plant cells and used for genome editing without the integration of foreign DNA because of degradation by endogenous proteases [93]. The protoplast transformation technique has been used to transform grape, apple, and lettuce with purified Cas9 RNPs. Sequencing analysis of transformed cells revealed mutagenesis efficiencies of 0.1 to $6.9 \%$ in grapevine and apple; however, due to the poor regeneration ability of protoplasts, no plants were regenerated $[93,94]$.

Two methods have been used to obtain transgene-free plants with mutations via CRISPR/Cas9 gene editing. The first is based on the site-specific recombinase flippase (Flp) [95], which recognises 34 bp-long flippase recognition target site (FRT) sequences. The Flp/FRT system has been extensively used to remove undesired transgenic components in transgenic apple $[96,97]$. The second removal method relies on the Cas 9 enzyme cleavage mechanism. Two additional synthetic target sites, referred to as cleavage target sites, were added next to the left border (LB) and right border (RB) sites of the CRISPR/Cas9 vector. When plants are transformed using CRISPR/Cas9, the Cas9 cleavage activity not only edits the endogenous target site, but also removes T-DNA by inserting two additional cleavage target sites, thereby resulting in T-DNA-free plants [98].

\subsubsection{Novel Variants of Cas Protein and Applications}

In commonly used CRISPR-Cas9 systems, the Streptococcus pyogenes (SpCas9)-gRNA complex generally recognises the region $20 \mathrm{nt}$ upstream of the PAM sequence $\left(5^{\prime}-\mathrm{NGG}-3^{\prime}\right)$. To broaden the Cas 9 protein recognition sequence and reduce the off-target editing rate, several approaches have been used to broaden PAM compatibility and enhance specificity. These approaches are based on the structural characteristics of SpCas9 binding to gRNA and target DNA. For example, the Cas9 variants SpCas9-VQR (NGA-PAM), SpCas9-EQR (NGAG-PAM), and SpCas9-VRER (NGCG-PAM) functioned, but their cleavage activity levels were lower compared to that of the wild-type SpCas9 in Arabidopsis and rice [99-102]. SpCas9-NG has a broader recognition sequence with enhanced compatibility, recognising NG-PAM, and has successfully generated targeted mutations in rice and Arabidopsis [103-105].

The variants SpCas9-HF1, eSpCas9, and HypaCas9 have been developed to enhance Cas9 protein-cleavage specificity. They show reduced off-target editing activities, indicating high specificity in plant cells [106-108]. Cas9 protein-directed evolution has been developed 
for Cas9 engineering, conferring high-specificity engineered SpCas9 proteins such as xCas9 [109], evoCas9 [110], and Sniper-Cas9 [111]. xCas9 recognises the NG, GAA, and GAT PAM sequences. Although the gRNA containing these PAM sequences can be mutated in plants, the mutation efficiencies and the preferences for different corresponding PAM sequences differ between cells. For example, the cleavage activity of xCas9 is lower in rice callus than in mammalian cells [112], and xCas9 does not recognise the NG-PAM sequence in tomatoes [32]. Cas9-NG has a stronger cleavage activity than $\mathrm{xCas9}$, especially at CGG, AGC, TGA, and CGT sequence recognition sites [98], making Cas9-NG more suitable for genome editing at the NG-PAM site in plants. The single-base editing system developed based on Cas9 variants (SpCas9-NG and SpCas9-VQR) has been applied to precise base-editing of plant genomes [103,113].

At present, the most commonly used Cas9 protein comes from Streptococcus pyogenes, in order to broaden the Cas9 protein recognition sequence, orthologous Cas 9 proteins have been isolated from other bacteria; for instance, NmCas9 has been isolated from Neisseria meningitidis [114], SaCas9 from Staphylococcus aureus [115], StCas9 from Streptococcus thermophilus [116], FnCas9 from Francisella novicida [117], and CjCas9 from Campylobacter jejuni [118]. These proteins are smaller than SpCas9, which is an advantage in cassette delivery. In Arabidopsis, the SaCas9 and SpCas9 systems do not interfere with each other [119], so they can fully utilise Cas9 orthologues that recognise different PAM sequences. Such simultaneous targeting by Cas 9 orthologues with different PAM sequences would enable multiplex genome engineering by simultaneously targeting more than one site.

With the continued discovery and investigation of the functions of CRISPR protein family members, new types of Cas proteins have been discovered including the type VI CRISPR-Cas system Cas13 (C2c2) protein, which recognises RNA sequences and exhibits RNA editing activity without altering the genome sequence $[120,121]$. This system has been successfully applied to knockout gene function in rice and tobacco and promote resistance to RNA viruses in Arabidopsis [121,122]. Likewise, the CRISPR-Cas13 system created RNA-guided immunity against RNA viruses in plants. Type V CRISPR-Cas systems, such as Cas12c, Cas12g, Cas12h, Cas12i, and Cas14, are distinguished according to the type of their target template (ssRNA, ssDNA, dsDNA, or ssDNA) and cleavage activity strength. Their functions range from dsDNA nicking and cleavage, and can have collateral cleavage activity on ssRNA, ssDNA, dsDNA, and ssDNA [123,124]. In short, the functional differentiation of these Cas protein variants can be used to target mutations in different nucleic acid types, induce a small number of $100 \mathrm{~kb}$ sequence deletions, and expand the repertoire of plant genome-editing tools.

\subsection{Regulatory Framework of CRISPR-Cas-Edited Crops}

During CRISPR-Cas gene editing of plants, Cas cuts the target sequence to produce double-strand breaks, resulting in the loss of gene function. The CRISPR-Cas technique has been utilised to create modifications in the genome that are identical to natural genetic variation [94]. Similarly, in HDR (homologous DNA repair) of CRISPR-Cas-mediated dsDNA fragmentation, exogenously provided homologous DNA sequences are deemed transgenic; however, when the repair template is derived from the genes from the same species and related interbreeding species, the resultant crops are not regarded as transgenic crops [125]. Nevertheless, the regulatory framework regarding NHEJ and HDR-mediated gene editing contains differing definitions.

The United States Department of Agriculture (USDA), FDA, and Environmental Protection Agency state that the removal of transgenic elements in plants by CRISPR-mediated editing is equivalent to crop improvement by conventional breeding programs, and crops generated in this way are thus not considered GMOs for regulatory purposes [126]. In 2016, the USDA approved the marketing of gene-edited waxy corn without exogenous transgenic elements [127], and an Agaricus bisporus mushroom with an anti-browning trait obtained from CRISPR-Cas9 editing was exempted from GMO regulatory procedures [128]. This definition of gene-edited crops by the United States regulatory agencies promotes the 
genetic improvement of crops and accelerates the introduction of gene-edited crops to the market. Genome editing has emerged as a powerful and elegant technology to develop novel varieties or organisms with desirable traits in tomato, citrus, soybean, sugarcane, camelina, and rice. In May 2020, the USDA-APHIS issued the latest edition of biotechnology regulations that provide three exemptions for genetic modifications in any plant species: (i) resultant changes in DNA after DSB in the absence of an external repair donor template; (ii) single base pair substitution in targeted loci; and (iii) introduction of a known gene that exists in the plant's gene pool.

As a major producer of GM crops, Canada considers gene-edited products such as plants, animal feed, or human food as different from nonedited products, so they must undergo a premarket assessment. In Europe, there are stringent regulations regarding CRISPR/Cas9, and the European Court of Justice has included gene-edited crops in the scope of GM crop regulation [129]. Australia has taken a milder approach, allowing geneediting without the introduction of any foreign genetic material [130]. In Asia, the attitude towards gene-edited crops has eased in China and Japan, and cases of gene-edited crops being planted in the field have been reported [131]. In addition, some countries have regulatory frameworks that are applied case-by-case, considering the breeding methodology used, new traits or characteristics introduced, and evidence of the genetic changes in the final product.

\section{Future Challenges in the Application of CRISPR-Cas Gene Editing}

CRISPR-Cas9 genome editing has been introduced and used to obtain abundant germplasm resources with genetic variation, thanks to the results of whole genome sequencing and functional genomics studies in fruit and vegetable crops. Nonetheless, its future application faces two major challenges. The first is the accurate selection of key genes for targeted mutations and the corresponding types of mutations. Important agronomic traits are often complex quantitative traits and editing a single gene does not produce phenotypic changes. Therefore, efficient CRISPR-Cas-mediated target site-specific insertion and chromosome recombination methods can be used to accumulate mutant alleles [132].

The use of gene-editing technology to inhibit the expression of specific genes in plants reduces their adaptability. Therefore, precise genome editing requires efficient and specific regulation of gene functions. Mutations in the exons of genes can change the function of proteins, and mutations in the exon-intron splice sites can result in different alternative splicing variants. Cis-regulatory elements (CREs) are noncoding DNA sequences that often serve to regulate gene transcription. In CREs, single-nucleotide mutations, insertions, deletions, inversions, and epigenetic variations in gene regulatory regions are closely associated with crop domestication [133]. The CRISPR-Cas system has been used to create mutations in the regulatory regions of promoters, and to generate a number of alleles with variable phenotypes, which serve as excellent genetic resources in breeding programs. Currently, the gene editing of CREs in fruit and vegetable crops is still in its preliminary stages. Future studies are aimed at associating changes in expression produced by different mutant CREs with the corresponding phenotypes and obtaining abundant breeding resources through gene editing of CREs. Target induction of DSBs using CRISPRCas results not only in small mutations, such as base substitutions, insertions, and deletions, but also large rearrangements of the genome, including large deletions, chromosomal translocations, and inversion, which is an efficient way to completely delete undesired genes, such as those encoding allergens, in fruit and vegetable crops [134-136]. Although such chromosomal rearrangements occur at a lower frequency than with conventional targeted mutagenesis, a deficiency of Ku70, which is involved in the NHEJ pathway, increases the frequency of inversion and translocation (Figure 3) [135].

The second challenge in the application of gene-editing technology is transforming the CRISPR-Cas gene-editing system into plant cells and obtaining regenerated plants. Genetic mutation vector systems mediated by conventional Cas9 or Cas variants, and precise geneediting systems mediated by $\mathrm{CBE}, \mathrm{ABE}$, and prime editing, have been successfully applied 
in model crops such as rice, corn, tobacco, and tomatoes, via Agrobacterium, gene gun, polyethylene glycol (PEG), and electroporation-based methods, providing a foundation for application in other crops [137]. However, developing a universal and efficient genetic transformation and regeneration system for fruit and vegetable crops is more difficult. In particular, the genetic transformation efficiency of CRISPR-Cas cassettes, and the ability of transformed tissues to regenerate plants, have become limiting factors. To improve explant regeneration ability after transformation, and meristem induction activity, the plant morphogenesis regulatory genes Bbm (baby boom) and Wus2 (Wuschel2) can be overexpressed at the same time as CRISPR-Cas expression cassette transformation [138]. Using plant RNA and DNA viruses as vectors to transform plant cells via CRISPR-Cas can provide sufficient sgRNAs and shorten and simplify the process of genetic transformation and regeneration, making this method suitable for in situ transformation, and facilitating the production of gene-edited plants without transgenic elements [139].

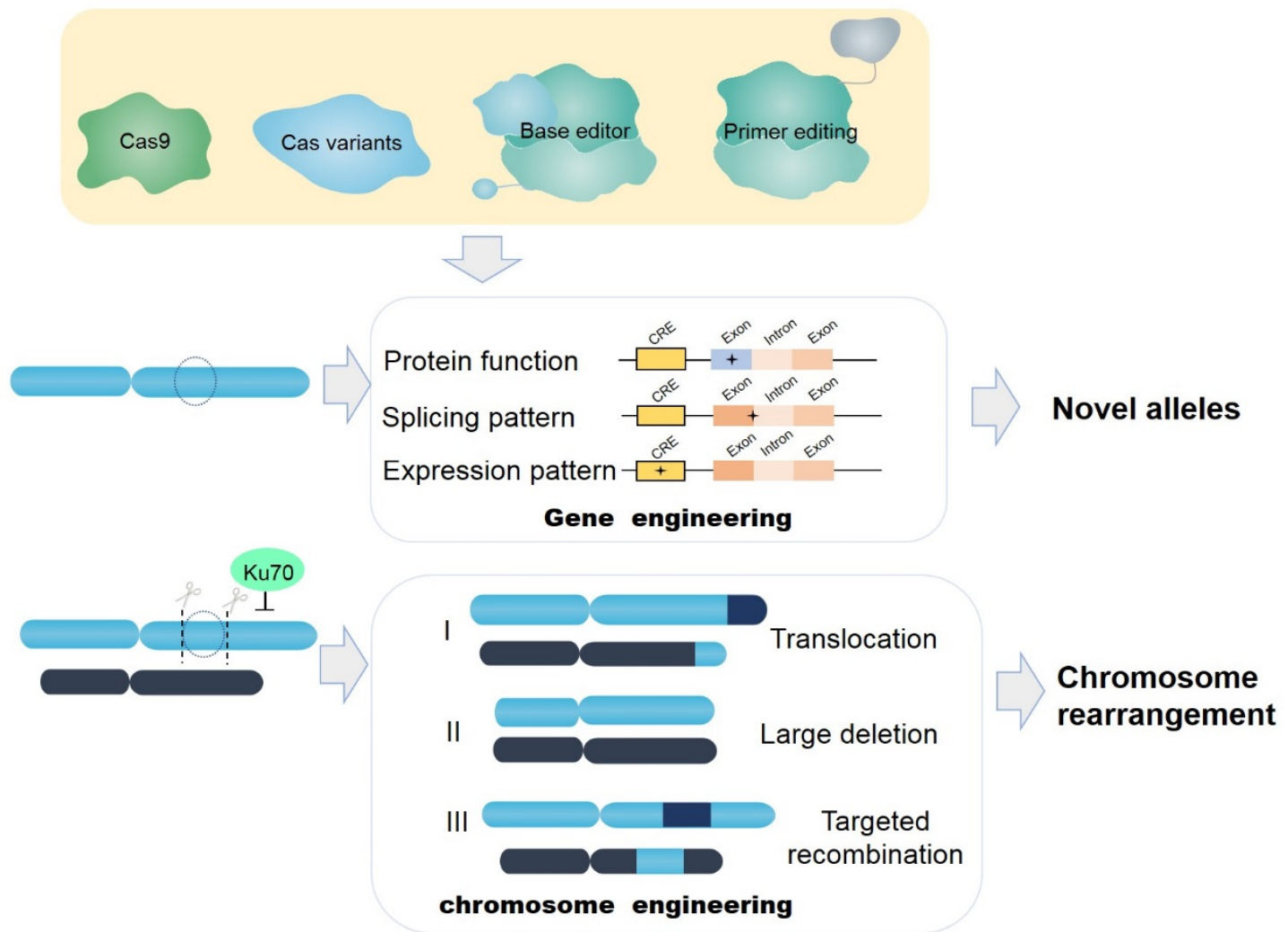

Figure 3. Genome-editing toolbox for trait improvement. CRISPR-Cas9, Cas9 variants, and base and primer editing enable precise gene modification and predictable rearrangement of genomes and chromosomes.

Author Contributions: This review was primarily conducted by L.W., Z.W., D.H., M.T., J.R., Y.S., N.Z. and H.Z., who were the contributors for the collection of the materials and revision of the manuscript. All authors have read and agreed to the published version of the manuscript.

Funding: This review was funded by the Natural Science Foundation of Hubei Province (2020CFB845), Innovation Research Foundation of Wuhan Academy of Agricultural Sciences (QNCX202110).

Institutional Review Board Statement: Not applicable.

Informed Consent Statement: Not applicable.

Acknowledgments: We appreciate internal review by Mao Donghai in Key Laboratory of AgroEcological Processes in Subtropical Region, Institute of Subtropical Agriculture, Chinese Academy of Sciences.

Conflicts of Interest: The authors declare no conflict of interest. 


\section{References}

1. Giovannoni, J.; Nguyen, C.; Ampofo, B.; Zhong, S.; Fei, Z. The Epigenome and Transcriptional Dynamics of Fruit Ripening. Ann. Rev. Plant Biol. 2017, 68, 61-84. [CrossRef]

2. Karkute, S.G.; Singh, A.K.; Gupta, O.P.; Singh, P.M.; Singh, B. CRISPR/Cas9 Mediated Genome Engineering for Improvement of Horticultural Crops. Front. Plant Sci. 2017, 8, 1635. [CrossRef]

3. Meyer, R.S.; Purugganan, M.D. Evolution of crop species: Genetics of domestication and diversification. Nat. Rev. Genet. 2013, 14, 840-852. [CrossRef]

4. Tester, M.; Langridge, P. Breeding technologies to increase crop production in a changing world. Science 2010, 327, 818-822. [CrossRef] [PubMed]

5. Bigliardi, B.; Galati, F. Innovation trends in the food industry: The case of functional foods. Trends Food Sci. Technol. 2013, 31, 118-129. [CrossRef]

6. Parmar, N.; Singh, K.H.; Sharma, D.; Singh, L.; Kumar, P.; Nanjundan, J.; Khan, Y.J.; Chauhan, D.K.; Thakur, A.K. Genetic engineering strategies for biotic and abiotic stress tolerance and quality enhancement in horticultural crops: A comprehensive review. 3 Biotech. 2017, 7, 239. [CrossRef] [PubMed]

7. Kramer, M.G.; Redenbaugh, K. Commercialization of a tomato with an antisense polygalacturonase gene: The FLAVR SAVR ${ }^{\mathrm{TM}}$ tomato story. Euphytica 1994, 79, 293-297. [CrossRef]

8. Millstone, E.; Stirling, A.; Glover, D. Regulating Genetic Engineering: The Limits and Politics of Knowledge. Issues Sci. Technol. 2015, 31, 23-26.

9. Bawa, A.S.; Anilakumar, K.R. Genetically modified foods: Safety, risks and public concerns-a review. J. Food Sci. Technol. 2013, 50, 1035-1046. [CrossRef]

10. Waltz, E. Gene-edited CRISPR mushroom escapes US regulation. Nature 2016, 7599, 293. [CrossRef]

11. Waltz, E. With a free pass, CRISPR-edited plants reach market in record time. Nat. Biotechnol. 2018, 36, 6-7. [CrossRef]

12. Jansen, R.; Embden, J.D.V.; Gaastra, W.; Schouls, L.M. Identification of genes that are associated with DNA repeats in prokaryotes. Mol. Microbiol. 2002, 43, 1565-1575. [CrossRef] [PubMed]

13. Bolotin, A. Clustered regularly interspaced short palindrome repeats (CRISPRs) have spacers of extrachromosomal origin. Microbiology 2005, 151, 2551-2561. [CrossRef]

14. Mojica, F.J.; Díez-Villaseñor, C.; García-Martínez, J.; Soria, E. Intervening sequences of regularly spaced prokaryotic repeats derive from foreign genetic elements. J. Mol. Evol. 2005, 60, 174-182. [CrossRef] [PubMed]

15. Pourcel, C. CRISPR elements in Yersinia pestis acquire new repeats by preferential uptake of bacteriophage DNA, and provide additional tools for evolutionary studies. Microbiology 2005, 151, 653-663. [CrossRef] [PubMed]

16. Cong, L.; Ran, F.A.; Cox, D.; Lin, S.; Barretto, R. Multiplex Genome Engineering Using CRISPR/Cas Systems. Science 2013, 339, 819-823. [CrossRef] [PubMed]

17. Kaboli, S.; Babazada, H. CRISPR Mediated Genome Engineering and its Application in Industry. Curr. Issues Mol. Biol. 2018, 26, 81-92. [CrossRef]

18. Shan, Q.; Wang, Y.; Li, J.; Zhang, Y.; Chen, K.; Liang, Z.; Zhang, K.; Liu, J.; Xi, J.J.; Qiu, J.L.; et al. Targeted genome modification of crop plants using a CRISPR-Cas system. Nat. Biotechnol. 2013, 31, 686-688. [CrossRef]

19. Rouillon, C.; Zhou, M.; Zhang, J.; Politis, A.; Beilsten-Edmands, V.; Cannone, G.; Graham, S.; Robinson, C.V.; Spagnolo, L.; White, M.F. Structure of the CRISPR interference complex CSM reveals key similarities with cascade. Mol. Cell 2013, 52, 124-134. [CrossRef]

20. Gasiunas, G.; Barrangou, R.; Horvath, P.; Siksnys, V. Cas9-crRNA ribonucleoprotein complex mediates specific DNA cleavage for adaptive immunity in bacteria. Proc. Natl. Acad. Sci. USA 2012, 109, 15539-15540. [CrossRef] [PubMed]

21. Doudna, J.A.; Charpentier, E. Genome editing. The new frontier of genome engineering with CRISPR-Cas9. Science 2014, 346, 1258096. [CrossRef]

22. Yin, K.; Gao, C.; Qiu, J.L. Progress and prospects in plant genome editing. Nat. Plants 2017, 3, 17107. [CrossRef] [PubMed]

23. Baltes, N.J.; Gil-Humanes, J.; Cermak, T.; Atkins, P.A.; Voytas, D.F. DNA replicons for plant genome engineering. Plant cell 2014, 26, 151-163. [CrossRef]

24. Endo, M.; Ishikawa, Y.; Osakabe, K.; Nakayama, S.; Kaya, H.; Araki, T.; Shibahara, K.-I.; Abe, K.; Ichikawa, H.; Valentine, L.; et al. Increased frequency of homologous recombination and T-DNA integration in Arabidopsis CAF-1 mutants. EMBO J. 2006, 25, 5579-5590. [CrossRef] [PubMed]

25. Gil-Humanes, J.; Wang, Y.; Liang, Z.; Shan, Q.; Ozuna, C.V.; Sánchez-León, S.; Baltes, N.J.; Starker, C.; Barro, F.; Gao, C.; et al. High-efficiency gene targeting in hexaploid wheat using DNA replicons and CRISPR/Cas9. Plant J. 2017, 89, 1251-1262. [CrossRef] [PubMed]

26. Ayathilaka, K.; Sheridan, S.D.; Bold, T.D.; Bochenska, K.; Logan, H.L.; Weichselbaum, R.R.; Bishop, D.K.; Connell, P.P. A chemical compound that stimulates the human homologous recombination protein RAD51. Proc. Natl. Acad. Sci. USA 2008, 105, 15848-15853. [CrossRef]

27. Donohoue, P.D.; Barrangou, R.; May, A.P. Advances in Industrial Biotechnology Using CRISPR-Cas Systems. Trends Biotechnol. 2018, 36, 134-146. [CrossRef]

28. Li, R.; Fu, D.; Zhu, B.; Luo, Y.; Zhu, H. CRISPR/Cas9-mediated mutagenesis of lncRNA1459 alters tomato fruit ripening. Plant J. 2019, 97, 795. [CrossRef] 
29. Liang, W.; van Wersch, S.; Tong, M.; Li, X. TIR-NB-LRR immune receptor SOC3 pairs with truncated TIR-NB protein CHS1 or TN2 to monitor the homeostasis of E3 ligase SAUL1. New Phytol. 2019, 221, 2054-2066. [CrossRef]

30. Mao, Y.; Yang, X.; Zhou, Y.; Zhang, Z.; Botella, J.R.; Zhu, J.-K. Manipulating plant RNA-silencing pathways to improve the gene editing efficiency of CRISPR/Cas9 systems. Genome Biol. 2018, 19, 149. [CrossRef]

31. Hess, G.T.; Tycko, J.; Yao, D.; Bassik, M.C. Methods and Applications of CRISPR-Mediated Base Editing in Eukaryotic Genomes. Mol. Cell 2017, 68, 26-43. [CrossRef]

32. Niu, Q.; Wu, S.; Li, Y.; Yang, X.; Liu, P.; Xu, Y.; Lang, Z. Expanding the scope of CRISPR/Cas9-mediated genome editing in plants using an xCas9 and Cas9-NG hybrid. J. Integr. Plant Biol. 2020, 62, 398-402. [CrossRef]

33. Brooks, C.; Nekrasov, V.; Lippman, Z.B.; Van Eck, J. Efficient gene editing in tomato in the first generation using the clustered regularly interspaced short palindromic repeats/CRISPR-associated9 system. Plant Physiol. 2014, 166, 1292-1297. [CrossRef] [PubMed]

34. Kulus, D. Genetic resources and selected conservation methods of tomato. J. Appl. Bot. Food Qual. 2018, 91, 135-144.

35. Ma, C.; Liu, M.; Li, Q.; Si, J.; Ren, X.; Song, H. Efficient BoPDS Gene Editing in Cabbage by the CRISPR/Cas9 System. Hortic. Plant J. 2019, 5, 164-169. [CrossRef]

36. Sun, B.; Zheng, A.; Jiang, M.; Xue, S.; Yuan, Q.; Jiang, L.; Chen, Q.; Li, M.; Wang, Y.; Zhang, Y.; et al. CRISPR/Cas9-mediated mutagenesis of homologous genes in Chinese kale. Sci. Rep. 2018, 8, 16786. [CrossRef] [PubMed]

37. Tian, S.; Jiang, L.; Gao, Q.; Zhang, J.; Zong, M.; Zhang, H.; Ren, Y.; Guo, S.; Gong, G.; Liu, F.; et al. Efficient CRISPR/Cas9-based gene knockout in watermelon. Plant Cell Rep. 2017, 36, 399-406. [CrossRef]

38. Bastet, A.; Zafirov, D.; Giovinazzo, N.; Guyon-Debast, A.; Nogué, F.; Robaglia, C.; Gallois, J.L. Mimicking natural polymorphism in eIF4E by CRISPR-Cas9 base editing is associated with resistance to potyviruses. Plant Biotechnol. J. 2019, 17, 1736-1750. [CrossRef]

39. Chandrasekaran, J.; Brumin, M.; Wolf, D.; Leibman, D.; Klap, C.; Pearlsman, M.; Sherman, A.; Arazi, T.; Gal-On, A. Development of broad virus resistance in non-transgenic cucumber using CRISPR/Cas9 technology. Mol. Plant Pathol. 2016, 17, 1140-1153. [CrossRef] [PubMed]

40. Ji, X.; Zhang, H.; Zhang, Y.; Wang, Y.; Gao, C. Establishing a CRISPR-Cas-like immune system conferring DNA virus resistance in plants. Nat. Plants 2015, 1, 15144. [CrossRef] [PubMed]

41. Ali, Z.; Ali, S.; Tashkandi, M.; Zaidi, S.S.E.A.; Mahfouz, M.M. CRISPR/Cas9-Mediated Immunity to Geminiviruses: Differential Interference and Evasion. Sci. Rep. 2016, 6, 26912. [CrossRef]

42. Borrelli, V.M.G.; Brambilla, V.; Rogowsky, P.; Marocco, A.; Lanubile, A. The Enhancement of Plant Disease Resistance Using CRISPR/Cas9 Technology. Frontiers in Plant Science. 2018, 9, 1245. [CrossRef] [PubMed]

43. Zeilmaker, T.; Ludwig, N.R.; Elberse, J.; Seidl, M.F.; Berke, L.; Van Doorn, A.; Schuurink, R.C.; Snel, B.; Van den Ackerveken, G. DOWNY MILDEW RESISTANT 6 and DMR6-LIKE OXYGENASE 1 are partially redundant but distinct suppressors of immunity in Arabidopsis. Plant J. 2015, 81, 210-222. [CrossRef] [PubMed]

44. Paula de Toledo Thomazella, D.; Brail, Q.; Dahlbeck, D.; Staskawicz, B. CRISPR-Cas9 mediated mutagenesis of a DMR6 ortholog in tomato confers broad-spectrum disease resistance. BioRxiv 2016, 064824. [CrossRef]

45. Nekrasov, V.; Wang, C.; Win, J.; Lanz, C.; Weigel, D.; Kamoun, S. Rapid generation of a transgene-free powdery mildew resistant tomato by genome deletion. Sci. Rep. 2017, 7, 1-6. [CrossRef]

46. Chaudhary, R.; Hs, A. Resistance-Gene-Mediated Defense Responses against Biotic Stresses in the Crop Model Plant Tomato. J. Plant Pathol. Microbiol. 2017, 8, 2.

47. Cahya, P.; Barbetti, M.J.; Barker, S.J. A Novel Tomato Fusarium Wilt Tolerance Gene. Front. Microbiol. 2018, 9, 1226.

48. Zhang, M.; Liu, Q.; Yang, X.; Xu, J.; Liu, G.; Yao, X.; Ren, R.; Xu, J.; Lou, L. CRISPR/Cas9-mediated mutagenesis of Clpsk1 in watermelon to confer resistance to Fusarium oxysporum f.sp. niveum. Plant Cell Rep. 2020, 39, 589-595. [CrossRef] [PubMed]

49. Shujuan, Z.; Liu, W.; Ruirui, Z.; Wenqing, Y.; Rui, L.; Yujing, L.; Jiping, S.; Lin, S. Knockout of SIMAPK3 Reduced Disease Resistance to Botrytis cinerea in Tomato Plants. J. Agric. Food Chem. 2018, 66, 8949-8956.

50. Andrés, O.; Selena, G.I.; Nathalie, L.; Roberto, S. Design of a bacterial speck resistant tomato by CRISPR/Cas9-mediated editing of S1JAZ2. Plant Biotechnol. J. 2018, 17, 665-673.

51. Haque, E.; Taniguchi, H.; Hassan, M.M.; Bhowmik, P.; Karim, M.R.; Śmiech, M.; Zhao, K.; Rahman, M.; Islam, T. Application of CRISPR/Cas9 Genome Editing Technology for the Improvement of Crops Cultivated in Tropical Climates: Recent Progress, Prospects, and Challenges. Front. Plant Sci. 2018, 9, 617. [CrossRef]

52. Yin, Y.; Qin, K.; Song, X.; Zhang, Q.; Zhou, Y.; Xia, X.; Yu, J. BZR1 Transcription Factor Regulates Heat Stress Tolerance Through FERONIA Receptor-Like Kinase-Mediated Reactive Oxygen Species Signaling in Tomato. Plant Cell Physiol. 2018, 59, 2239-2254. [CrossRef]

53. Li, R.; Zhang, L.; Wang, L.; Chen, L.; Zhao, R.; Sheng, J.; Shen, L. Reduction of Tomato-Plant Chilling Tolerance by CRISPR-Cas9Mediated SICBF1 Mutagenesis. J. Agric. Food Chem. 2018, 66, 9042-9051. [CrossRef] [PubMed]

54. Wang, L.; Chen, L.; Li, R.; Zhao, R.; Yang, M.; Sheng, J.; Shen, L. Reduced drought tolerance by CRISPR/Cas9-mediated SIMAPK3 mutagenesis in tomato plants. J. Agric. Food Chem. 2017, 65, 8674-8682. [CrossRef] [PubMed]

55. Tian, S.; Jiang, L.; Cui, X.; Zhang, J.; Guo, S.; Li, M.; Zhang, H.; Ren, Y.; Gong, G.; Zong, M. Engineering herbicide-resistant watermelon variety through CRISPR/Cas9-mediated base-editing. Plant Cell Rep. 2018, 37, 1353-1356. [CrossRef] 
56. Butler, N.M.; Atkins, P.A.; Voytas, D.F.; Douches, D.S. Generation and Inheritance of Targeted Mutations in Potato (Solanum tuberosum L.) Using the CRISPR/Cas System. PLoS ONE 2015, 10, e0144591. [CrossRef]

57. Bari, V.K.; Nassar, J.A.; Aly, R. CRISPR/Cas9 mediated mutagenesis of MORE AXILLARY GROWTH 1 in tomato confers resistance to root parasitic weed Phelipanche aegyptiaca. Sci. Rep. 2021, 11, 3905. [CrossRef] [PubMed]

58. Bari, V.K.; Nassar, J.A.; Kheredin, S.M.; Gal-On, A.; Ron, M.; Britt, A.; Steele, D.; Yoder, J.; Aly, R. CRISPR/Cas9-mediated mutagenesis of CAROTENOID CLEAVAGE DIOXYGENASE 8 in tomato provides resistance against the parasitic weed Phelipanche aegyptiaca. Sci. Rep. 2019, 9, 11438. [CrossRef] [PubMed]

59. Li, H.; Qi, M.; Sun, M.; Liu, Y.; Liu, Y.; Xu, T.; Li, Y.; Li, T. Tomato Transcription Factor SIWUS Plays an Important Role in Tomato Flower and Locule Development. Front. Plant Sci. 2017, 8, 457. [CrossRef]

60. Li, T.; Yang, X.; Yu, Y.; Si, X.; Zhai, X.; Zhang, H.; Dong, W.; Gao, C.; Xu, C. Domestication of wild tomato is accelerated by genome editing. Nat. Biotechnol. 2018, 36,1160-1163. [CrossRef]

61. Rodríguez-Leal, D.; Lemmon, Z.H.; Man, J.; Bartlett, M.E.; Lippman, Z.B. Engineering Quantitative Trait Variation for Crop Improvement by Genome Editing. Cell 2017, 171, 470-480. [CrossRef]

62. Lin, T.; Zhu, G.; Zhang, J.; Xu, X.; Yu, Q.; Zheng, Z.; Zhang, Z.; Lun, Y.; Li, S.; Wang, X.; et al. Genomic analyses provide insights into the history of tomato breeding. Nat. Genet. 2014, 46, 1220-1226. [CrossRef] [PubMed]

63. Ballester, A.R.; Molthoff, J.; de Vos, R.; Hekkert, B.T.L.; Orzaez, D.; Fernaündez-Moreno, J.P.; Tripodi, P.; Gran-dillo, S.; Martin, C.; Heldens, J.; et al. Biochemical and Molecular Analysis of Pink Tomatoes: Deregulated Expression of the Gene Encoding Transcription Factors SIMYB12 Leads to Pink Tomato Fruit Color. Plant Physiol. 2010, 152, 71-84. [CrossRef] [PubMed]

64. Čermák, T.; Baltes, N.J.; Čegan, R.; Zhang, Y.; Voytas, D.F. High-frequency, precise modification of the tomato genome. Genome Biol. 2015, 16, 232. [CrossRef] [PubMed]

65. Deng, L.; Wang, H.; Sun, C.; Li, Q.; Jiang, H.; Du, M.; Li, C.B.; Li, C. Efficient generation of pink-fruited tomatoes using CRISPR/Cas9 system. J. Genet. Genom. 2018, 45, 51-54. [CrossRef]

66. Filler Hayut, S.; Melamed Bessudo, C.; Levy, A.A. Targeted recombination between homologous chromosomes for precise breeding in tomato. Nat. Commun. 2017, 8, 15605. [CrossRef]

67. Sun, B.; Jiang, M.; Zheng, H.; Jian, Y.; Huang, W.L.; Yuan, Q.; Zheng, A.H.; Chen, Q.; Zhang, Y.T.; Lin, Y.X.; et al. Color-related chlorophyll and carotenoid concentrations of Chinese kale can be altered through CRISPR/Cas 9 targeted editing of the carotenoid isomerase gene BoaCRTISO. Hortic. Res. 2020, 7, 161. [CrossRef]

68. Chen, L.; Yang, D.; Zhang, Y. Evidence for a specific and critical role of mitogen-activated protein kinase 20 in uni-to-binucleate transition of microgametogenesis in tomato. Plant Biol. 2018, 219, 176-194. [CrossRef]

69. Kris-Etherton, P.M.; Hecker, K.D.; Bonanome, A.; Coval, S.M.; Binkoski, A.E.; Hilpert, K.F.; Griel, A.E.; Etherton, T.D. Bioactive compounds in foods: Their role in the prevention of cardiovascular disease and cancer. Am. J. Med. 2002, 113, 71-88. [CrossRef]

70. Meng, X.; Yang, D.; Li, X.; Zhao, S.; Sui, N.; Meng, Q. Physiological changes in fruit ripening caused by overexpression of tomato SlAN2, an R2R3-MYB factor. Plant Physiol. Biochem. 2015, 89, 24-30. [CrossRef]

71. Ye, J.; Wang, X.; Hu, T.; Zhang, F.; Wang, B.; Li, C.; Yang, T.; Li, H.; Lu, Y. An InDel in the Promoter of Al-ACTIVATED MALATE TRANSPORTER9 Selected during Tomato Domestication Determines Fruit Malate Contents and Aluminum Tolerance. Plant Cell 2017, 29, 2249. [CrossRef] [PubMed]

72. Nonaka, S.; Arai, C.; Takayama, M.; Matsukura, C.; Ezura, H. Efficient increase of $\gamma$-aminobutyric acid (GABA) content in tomato fruits by targeted mutagenesis. Sci. Rep. 2017, 7, 7057. [CrossRef]

73. Li, X.; Wang, Y.; Chen, S.; Tian, H.; Fu, D.; Zhu, B.; Luo, Y.; Zhu, H. Lycopene Is Enriched in Tomato Fruit by CRISPR/Cas9Mediated Multiplex Genome Editing. Front. Plant Sci. 2018, 9, 559. [CrossRef] [PubMed]

74. Nakayasu, M.; Akiyama, R.; Lee, H.J.; Osakabe, K.; Osakabe, Y.; Watanabe, B.; Sugimoto, Y.; Umemoto, N.; Saito, K.; Muranaka, T.; et al. Generation of $\alpha$-solanine-free hairy roots of potato by CRISPR/Cas9 mediated genome editing of the St16DOX gene. Plant Physiol. Biochem. 2018, 131, 70-77. [CrossRef] [PubMed]

75. Ito, Y.; Nishizawa-Yokoi, A.; Endo, M.; Mikami, M.; Toki, S. CRISPR/Cas9-mediated mutagenesis of the RIN locus that regulates tomato fruit ripening. Biochem. Biophys. Res. Commun. 2015, 467, 76-82. [CrossRef]

76. Lang, Z.; Wang, Y.; Tang, K.; Tang, D.; Datsenka, T.; Cheng, J.; Zhang, Y.; Handa, A.K.; Zhu, J.K. Critical roles of DNA demethylation in the activation of ripening-induced genes and inhibition of ripening-repressed genes in tomato fruit. Proc. Natl. Acad. Sci. USA 2017, 114, E4511-E4519. [CrossRef]

77. Wang, D.; Samsulrizal, A.; Yan, B.C.; Allcock, C.; Craigon, D.J. Characterization of CRISPR Mutants Targeting Genes Modulating Pectin Degradation in Ripening Tomato. Plant Physiol. 2019, 179, 544-557.

78. Yu, Q.H.; Wang, B.; Li, N.; Tang, Y.; Yang, S.; Yang, T.; Xu, J.; Guo, C.; Yan, P.; Wang, Q.; et al. CRISPR/Cas9-induced Targeted Mutagenesis and Gene Replacement to Generate Long-shelf Life Tomato Lines. Sci. Rep. 2017, 7, 11874. [CrossRef]

79. Ledford, H. Fixing the tomato: CRISPR edits correct plant-breeding snafu. Nature 2017, 545, 394-395. [CrossRef]

80. Soyk, S.; Lemmon, Z.H.; Oved, M.; Fisher, J.; Liberatore, K.L.; Park, S.J.; Goren, A.; Jiang, K.; Ramos, A.; van der Knaap, E.; et al. Bypassing Negative Epistasis on Yield in Tomato Imposed by a Domestication Gene. Cell 2017, 169, 1142-1155. [CrossRef]

81. Roldan, M.V.G.; Périlleux, C.; Morin, H.; Huerga-Fernandez, S.; Latrasse, D.; Benhamed, M.; Bendahmane, A. Natural and induced loss of function mutations in SIMBP21 MADS-box gene led to jointless-2 phenotype in tomato. Sci. Rep. 2017, 7, 1-10. [CrossRef] 
82. Klap, C.; Yeshayahou, E.; Bolger, A.M.; Arazi, T.; Gupta, S.K.; Shabtai, S.; Usadel, B.R.; Salts, Y.; Barg, R. Tomato facultative parthenocarpy results from SIAGAMOUS-LIKE 6 loss of function. Plant Biotechnol. J. 2016, 15, 634-647. [CrossRef] [PubMed]

83. $\mathrm{Hu}, \mathrm{J} . ;$ Alon, I.; Naomi, O.; Sun, T.P. DELLA-ARF/IAA Interaction Mediates Crosstalk between Gibberellin and Auxin Signaling in Controlling Fruit Initiation in Solanum lycopersicum. Plant Cell 2018, 30, 1710-1728. [CrossRef] [PubMed]

84. Ueta, R.; Abe, C.; Watanabe, T.; Sugano, S.S.; Ishihara, R.; Ezura, H.; Osakabe, Y.; Osakabe, K. Rapid breeding of parthenocarpic tomato plants using CRISPR/Cas9. Sci. Rep. 2017, 7, 507. [CrossRef] [PubMed]

85. Xu, C.; Park, S.J.; Van Eck, J.; Lippman, Z.B. Control of inflorescence architecture in tomato by BTB/POZ transcriptional regulators. Genes Dev. 2016, 30, 2048-2061. [CrossRef]

86. Zsögön, A.; Čermák, T.; Naves, E.R.; Notini, M.M.; Edel, K.H.; Weinl, S.; Freschi, L.; Voytas, D.F.; Kudla, J.; Peres, L.E.P. De novo domestication of wild tomato using genome editing. Nat. Biotechnol. 2018, 36, 1211-1216. [CrossRef] [PubMed]

87. Wang, R.; Tavano, E.C.d.R.; Lammers, M.; Martinelli, A.P.; Angenent, G.C.; de Maagd, R.A. Re-evaluation of transcription factor function in tomato fruit development and ripening with CRISPR/Cas9-mutagenesis. Sci. Rep. 2019, 9, 1696. [CrossRef] [PubMed]

88. Soyk, S.; Müller, N.A.; Park, S.J.; Schmalenbach, I.; Jiang, K.; Hayama, R.; Zhang, L.; Van Eck, J.; Jiménez-Gómez, J.M.; Lippman, Z.B. Variation in the flowering gene SELF PRUNING 5G promotes day-neutrality and early yield in tomato. Nat. Genet. 2017, 49, 162-168. [CrossRef]

89. Zsögön, A.; Cermak, T.; Voytas, D.; Peres, L.E. Genome editing as a tool to achieve the crop ideotype and de novo domestication of wild relatives: Case study in tomato. Plant Sci. 2017, 256, 120-130. [CrossRef] [PubMed]

90. Bisognin, D.A. Breeding vegetatively propagated horticultural crops. Crop Breed. Appl. Biotechnol. 2011, 11, 35-43. [CrossRef]

91. Corte, E.D.; MMahmoud, L.; SMoraes, T.; Mou, Z.; WGrosser, J.; Dutt, M. Development of Improved Fruit, Vegetable, and Ornamental Crops Using the CRISPR/Cas9 Genome Editing Technique. Plants 2019, 8, 601. [CrossRef]

92. Charrier, A.; Vergne, E.; Dousset, N.; Richer, A.; Petiteau, A.; Chevreau, E. Efficient Targeted Mutagenesis in Apple and First Time Edition of Pear Using the CRISPR-Cas9 System. Front. Plant Sci. 2019, 10, 40. [CrossRef]

93. Malnoy, M.; Viola, R.; Jung, M.H.; Koo, O.J.; Kim, S.; Kim, J.S.; Velasco, R.; Nagamangala Kanchiswamy, C. DNA-Free Genetically Edited Grapevine and Apple Protoplast Using CRISPR/Cas9 Ribonucleoproteins. Front. Plant Sci. 2016, 7, 1904. [CrossRef]

94. Woo, J.W.; Kim, J.; Kwon, S.I.; Corvalán, C.; Cho, S.W.; Kim, H.; Kim, S.G.; Kim, S.T.; Choe, S.; Kim, J.S. DNA-free genome editing in plants with preassembled CRISPR-Cas9 ribonucleoproteins. Nat. Biotechnol. 2015, 33, 1162-1164. [CrossRef]

95. Pompili, V.; Dalla Costa, L.; Piazza, S.; Pindo, M.; Malnoy, M. Reduced fire blight susceptibility in apple cultivars using a high-efficiency CRISPR/Cas9-FLP/FRT-based gene editing system. Plant Biotechnol. J. 2020, 18, 845-858. [CrossRef] [PubMed]

96. Dalla Costa, L.; Piazza, S.; Campa, M.; Flachowsky, H.; Hanke, M.-V.; Malnoy, M. Efficient heat-shock removal of the selectable marker gene in genetically modified grapevine. Plant Cell Tissue Organ Cult. 2016, 124, 471-481. [CrossRef]

97. Herzog, K.; Flachowsky, H.; Deising, H.B.; Hanke, M.V. Heat-shock-mediated elimination of the nptII marker gene in transgenic apple (Malus $\times$ domestica Borkh.). Gene 2012, 498, 41-49. [CrossRef]

98. Dalla Costa, L.; Piazza, S.; Pompili, V.; Salvagnin, U.; Cestaro, A.; Moffa, L.; Vittani, L.; Moser, C.; Malnoy, M. Strategies to produce T-DNA free CRISPRed fruit trees via Agrobacterium tumefaciens stable gene transfer. Sci. Rep. 2020, 10, 1-14. [CrossRef] [PubMed]

99. Akihiro, Y.; Takashi, I.; Mika, Y.; Yuri, K.; Shinichiro, S. Developing Heritable Mutations in Arabidopsis thaliana Using a Modified CRISPR/Cas9 Toolkit Comprising PAM-Altered Cas9 Variants and gRNAs. Plant Cell Physiol. 2019, 60, $2255-2262$.

100. Hu, X.; Meng, X.; Liu, Q.; Li, J.; Wang, K. Increasing the efficiency of CRISPR-Cas9-VQR precise genome editing in rice. Plant Biotechnol. J. 2018, 16, 292-297. [CrossRef] [PubMed]

101. Hu, X.; Wang, C.; Fu, Y.; Liu, Q.; Jiao, X.; Wang, K. Expanding the Range of CRISPR/Cas9 Genome Editing in Rice. Mol. Plant 2016, 9, 943-945. [CrossRef]

102. Kleinstiver, B.P.; Prew, M.S.; Tsai, S.Q.; Topkar, V.V.; Nguyen, N.T.; Zheng, Z.; Gonzales, A.P.W.; Li, Z.; Peterson, R.T.; Yeh, J.-R.J.; et al. Engineered CRISPR-Cas9 nucleases with altered PAM specificities. Nature 2015, 523, 481-485. [CrossRef] [PubMed]

103. Hua, K.; Tao, X.; Han, P.; Wang, R.; Zhu, J.K. Genome Engineering in Rice Using Cas9 Variants that Recognize NG PAM Sequences. Mol. Plant 2019, 12, 1003-1014. [CrossRef]

104. Endo, M.; Mikami, M.; Endo, A.; Kaya, H.; Itoh, T.; Nishimasu, H.; Nureki, O.; Toki, S. Genome editing in plants by engineered CRISPR-Cas9 recognizing NG PAM. Nat. Plants 2019, 5, 14-17. [CrossRef]

105. Zhong, Z.; Sretenovic, S.; Ren, Q.; Yang, L.; Bao, Y.; Qi, C.; Yuan, M.; He, Y.; Liu, S.; Liu, X.; et al. Improving Plant Genome Editing with High-Fidelity xCas9 and Non-canonical PAM-Targeting Cas9-NG. Mol. Plant 2019, 12, 1027-1036. [CrossRef]

106. Kleinstiver, B.P.; Pattanayak, V.; Prew, M.S.; Tsai, S.Q.; Nguyen, N.T.; Zheng, Z.; Joung, J.K. High-fidelity CRISPR-Cas9 nucleases with no detectable genome-wide off-target effects. Nature 2016, 529, 490-495. [CrossRef] [PubMed]

107. Slaymaker, I.M.; Gao, L.; Zetsche, B.; Scott, D.A.; Yan, W.X.; Zhang, F. Rationally engineered Cas9 nucleases with improved specificity. Science 2016, 351, 84-88. [CrossRef] [PubMed]

108. Zhang, D.; Zhang, H.; Li, T.; Chen, K.; Qiu, J.L.; Gao, C. Perfectly matched 20-nucleotide guide RNA sequences enable robust genome editing using high-fidelity SpCas9 nucleases. Genome Biol. 2017, 18, 191. [CrossRef] [PubMed]

109. Hu, J.H.; Miller, S.M.; Geurts, M.H.; Tang, W.; Chen, L.; Sun, N.; Zeina, C.M.; Gao, X.; Rees, H.A.; Lin, Z.; et al. Evolved Cas9 variants with broad PAM compatibility and high DNA specificity. Nature 2018, 556, 57-63. [CrossRef] [PubMed]

110. Casini, A.; Olivieri, M.; Petris, G.; Bianchi, A.; Montagna, C.; Reginato, G.; Maule, G.; Lorenzin, F.; Prandi, D.; Romanel, A.; et al. Evocas9, a highly specific SpCas9 variant from a yeast in vivo screening. Nat. Biotechnol. 2018, 36, 265-271. [CrossRef] 
111. Lee, J.K.; Jeong, E.; Lee, J.; Jung, M.; Shin, E.; Kim, Y.-H.; Lee, K.; Jung, I.; Kim, D.; Kim, S.; et al. Directed evolution of CRISPR-Cas9 to increase its specificity. Nat. Commun. 2018, 9, 3048. [CrossRef]

112. Wang, J.; Meng, X.; Hu, X.; Sun, T.; Li, J.; Wang, K.; Yu, H. xCas9 expands the scope of genome editing with reduced efficiency in rice. Plant Biotechnol. J. 2019, 17, 709-711. [CrossRef] [PubMed]

113. Wu, Y.; Xu, W.; Wang, F.; Zhao, S.; Yang, J. Increasing Cytosine Base Editing Scope and Efficiency With Engineered Cas9-PmCDA1 Fusions and the Modified sgRNA in RiceData_Sheet_1.docx. Front. Genet. 2019, 10, 379. [CrossRef]

114. Hou, Z.; Zhang, Y.; Propson, N.E.; Howden, S.E.; Chu, L.F.; Sontheimer, E.J.; Thomson, J.A. Efficient genome engineering in human pluripotent stem cells using Cas9 from Neisseria meningitidis. Proc. Natl. Acad. Sci. USA 2013, 110, 15644-15649. [CrossRef] [PubMed]

115. Ran, F.A.; Cong, L.; Yan, W.X.; Scott, D.A.; Gootenberg, J.S.; Kriz, A.J.; Zetsche, B.; Shalem, O.; Wu, X.; Makarova, K.S.; et al. In vivo genome editing using Staphylococcus aureus Cas9. Nature 2015, 520, 186-191. [CrossRef] [PubMed]

116. Müller, M.; Lee, C.M.; Gasiunas, G.; Davis, T.H.; Cradick, T.J.; Siksnys, V.; Bao, G.; Cathomen, T.; Mussolino, C. Streptococcus thermophilus CRISPR-Cas9 Systems Enable Specific Editing of the Human Genome. Mol. Ther. 2016, 24, 636-644. [CrossRef]

117. Hirano, H.; Gootenberg, J.S.; Horii, T.; Abudayyeh, O.O.; Kimura, M.; Hsu, P.D.; Nakane, T.; Ishitani, R.; Hatada, I.; Zhang, F. Structure and Engineering of Francisella novicida Cas9. Cell 2016, 164, 950-961. [CrossRef]

118. Kim, E.; Koo, T.; Park, S.W.; Kim, D.; Kim, K.; Cho, H.Y.; Song, D.W.; Lee, K.J.; Jung, M.H.; Kim, S.; et al. In vivo genome editing with a small Cas9 orthologue derived from Campylobacter jejuni. Nat. Commun. 2017, 8, 14500. [CrossRef]

119. Steinert, J.; Schiml, S.; Fauser, F.; Puchta, H. Highly efficient heritable plant genome engineering using Cas 9 orthologues from Streptococcus thermophilus and Staphylococcus aureus. Plant J. 2015, 84, 1295-1305. [CrossRef]

120. Abudayyeh, O.O.; Gootenberg, J.S.; Konermann, S.; Joung, J.; Slaymaker, I.M.; Cox, D.B.; Shmakov, S.; Makarova, K.S.; Semenova, E.; Minakhin, L.; et al. C2c2 is a single-component programmable RNA-guided RNA-targeting CRISPR effector. Science 2016, 353, aaf5573. [CrossRef]

121. Cox, D.B.T.; Gootenberg, J.S.; Abudayyeh, O.O.; Franklin, B.; Kellner, M.J.; Joung, J.; Zhang, F. RNA editing with CRISPR-Cas13. Science 2017, 358, 1019-1027. [CrossRef] [PubMed]

122. Aman, R.; Ali, Z.; Butt, H.; Mahas, A.; Aljedaani, F.; Khan, M.Z.; Ding, S.; Mahfouz, M. RNA virus interference via CRISPR/Cas13a system in plants. Genome Biol. 2018, 19, 1-9. [CrossRef] [PubMed]

123. Harrington, L.B.; Burstein, D.; Chen, J.S.; Paez-Espino, D.; Ma, E.; Witte, I.P.; Cofsky, J.C.; Kyrpides, N.C.; Banfield, J.F.; Doudna, J.A. Programmed DNA destruction by miniature CRISPR-Cas14 enzymes. Science 2018, 362, 839-842. [CrossRef] [PubMed]

124. Yan, W.X.; Hunnewell, P.; Alfonse, L.E.; Carte, J.M.; Keston-Smith, E.; Sothiselvam, S.; Garrity, A.J.; Chong, S.; Makarova, K.S.; Koonin, E.V.; et al. Functionally diverse type V CRISPR-Cas systems. Science 2019, 363, 88. [CrossRef]

125. Kim, H.; Kim, J.S. A guide to genome engineering with programmable nucleases. Nat. Rev. Genet. 2014, 15, 321-334. [CrossRef] [PubMed]

126. Globus, R.; Qimron, U. A technological and regulatory outlook on CRISPR crop editing. J. Cell Biochem. 2018, 119, 1291-1298. [CrossRef]

127. USDA Re: Confirmation of Regulatory Status of Waxy Com Developed by CRISPR-Cas Technology. Available online: https: //www.aphis.usda.gov/biotechnology/downloads/reg_loi/15-352-01_air_response_signed.pdf (accessed on 2 October 2020).

128. USDA Re: Request for Confirmation that Transgene-Free, CRISPR-Edited Mushroom Is Not a Regulated Article. Available online: https: / / www.aphis.usda.gov/biotechnology/downloads/reg_loi/15-321-01_air_response_signed.pdf (accessed on 2 October 2020).

129. Callaway, E. CRISPR plants now subject to tough GM laws in European Union. Nature 2018, 560, 16. [CrossRef]

130. Mallapaty, S. Australian gene-editing rules adopt 'middle ground'. Nature 2019. [CrossRef]

131. Metje-Sprink, J.; Sprink, T.; Hartung, F. Genome-edited plants in the field. Curr. Opin. Biotechnol. 2020, 61, 1-6. [CrossRef]

132. Zhu, H.; Li, C.; Gao, C. Applications of CRISPR-Cas in agriculture and plant biotechnology. Nat. Rev. Mol. Cell Biol. 2020, 21, 661-677. [CrossRef]

133. Li, Q.; Sapkota, M.; van der Knaap, E. Perspectives of CRISPR/Cas-mediated cis-engineering in horticulture: Unlocking the neglected potential for crop improvement. Hortic. Res. 2020, 7, 36. [CrossRef] [PubMed]

134. Schmitz, D.J.; Ali, Z.; Wang, C.; Aljedaani, F.; Hooykaas, P.J.J.; Mahfouz, M.; de Pater, S. CRISPR/Cas9 Mutagenesis by Translocation of Cas9 Protein Into Plant Cells via the Agrobacterium Type IV Secretion System. Front. Genome Ed. $2020,2,6$. [CrossRef]

135. Schmidt, C.; Pacher, M.; Puchta, H. Efficient induction of heritable inversions in plant genomes using the CRISPR/Cas system. Plant J. 2019, 98, 577-589. [CrossRef]

136. Beying, N.; Schmidt, C.; Pacher, M.; Houben, A.; Puchta, H. CRISPR-Cas9-mediated induction of heritable chromosomal translocations in Arabidopsis. Nat. Plants 2020, 6, 638-645. [CrossRef]

137. Chuang, Y.F.; Phipps, A.J.; Lin, F.L.; Hecht, V.; Hewitt, A.W.; Wang, P.Y.; Liu, G.S. Approach for in vivo delivery of CRISPR/Cas system: A recent update and future prospect. Cell Mol. Life Sci. 2021, 78, 2683-2708. [CrossRef]

138. Lowe, K.; Wu, E.; Wang, N.; Hoerster, G.; Hastings, C.; Cho, M.J.; Scelonge, C.; Lenderts, B.; Chamberlin, M.; Cushatt, J.; et al. Morphogenic Regulators Baby boom and Wuschel Improve Monocot Transformation. Plant Cell 2016, 28, 1998-2015. [CrossRef]

139. Ali, Z.; Abul-faraj, A.; Li, L.; Ghosh, N.; Piatek, M.; Mahjoub, A.; Aouida, M.; Piatek, A.; Baltes, N.J.; Voytas, D.F.; et al. Efficient Virus-Mediated Genome Editing in Plants Using the CRISPR/Cas9 System. Mol. Plant 2015, 8, 1288-1291. [CrossRef] [PubMed] 